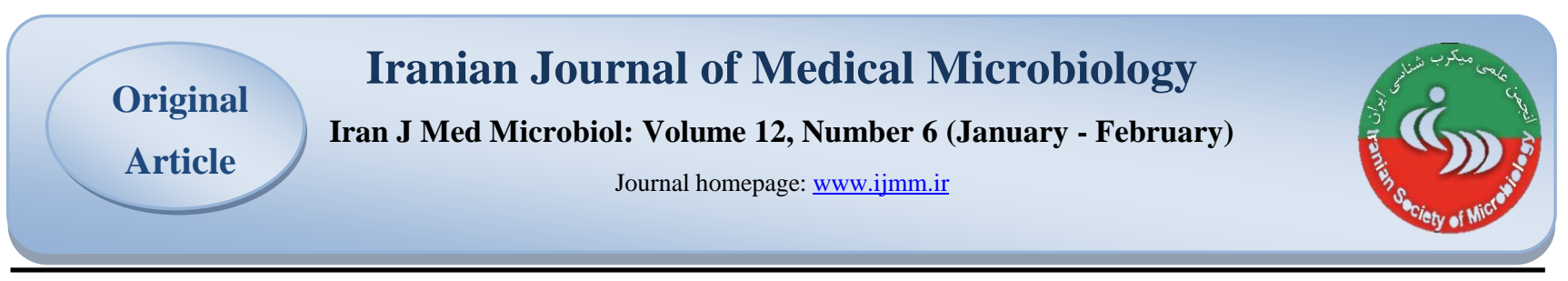

\title{
Phenotypic Investigation of Biofilm Formation and the Prevalence of icaA and icaD Genes in Staphylococcus epidermidis Isolates
}

\author{
Teena Dadgar $^{* 1}$, Zahra Vahedi', Sajjad Yazdansatad², Elahe Kiaei ${ }^{3}$, Hanieh Asaadi ${ }^{4}$ \\ 4. Department of Microbiology and Parasitology, Faculty of Medicine, Bushehr University of Medical Sciences, Bushehr, Iran
}

1. Department of Biology, Gorgan Branch, Islamic Azad University, Gorgan, Iran

2. Department of Microbiology, School of Medicine, Golestan University of Medical Sciences, Gorgan, Iran

3. Young Researchers Club, Gorgan Branch, Islamic Azad University, Gorgan, Iran

\section{Article Information}

\section{Article history:}

Received: 2018/12/05

Accepted: 2019/01/03

Available online: 2019/03/06

\section{Article Subject: \\ Medical Bacteriology}

IJMM 2019; 12(6): 371-381

Corresponding author:

\section{Teena Dadgar}

Department of Biology, Gorgan Branch, Islamic Azad University, Gorgan, Iran

Email:

dadgar_teena@yahoo.com

Use your device to scan and read the article online

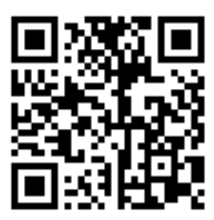

\section{Abstract}

Background and Aims: The most important factor for pathogenicity of Staphylococcus epidermidis is the ability to produce biofilm. Identification of biofilm-forming strains using an appropriate method and recognizing the mechanisms of biofilm formation can help understand the proper use of artificial medical equipment and prevent increased drugs resistance. The aim of this study was to 1) evaluate the biofilm formation of S. epidermidis isolates using phenotypic methods such as Tube Method (TM), Congo Red Agar Method (CRA) and Microtiter Plates Method (MTP) as well as PCR of the genes icaA and icaD 2) determine the drug resistance pattern of $S$. epidermidis isolates and its association with biofilm formation among clinical specimens and samples of healthy carriers.

Materials and Methods: A total of 90 strains of S. epidermidis including 50 clinical isolates and 40 strains from healthy carriers were studied using the phenotypic methods TM, CRA and MTP, and the molecular PCR of the genes icaA and icaD. Antibiotic resistance profile of the strains was performed using disk diffusion method according to the CLSI standards.

Results: A total of 90 strains ( $63.34 \%$ by TM, $37.78 \%$ by CRA method and $67.79 \%$ of MTP method) were able to form biofilm. No significant differences were found between the healthy and carriers groups in terms of antibiotic resistance. The icaA and icaD genes were detected among $100 \%$ and $85.24 \%$ of the biofilm forming strains, respectively.

Conclusions: Comparing the phenotypic and molecular methods for the detection of biofilm formation among $S$. epidermidis isolatesshowed that MTP is the best method with the highest sensitivity and specificity and its simultaneous use with molecular methods is recommended.

Keywords: Staphylococcus epidermidis, Biofilm, Antibiotic resistance, PCR.

Copyright $\odot$ 2019, Iran J Med Microbiol This is an open-access article distributed under the terms of the Creative Commons Attribution-noncommercial 4.0 International License which permits copy and redistribute the material just in noncommercial usages, provided the original work is properly cited.

How to cite this:

Dadgar T, Vahedi Z, Yazdansetad S, Kiaei E, Asaadi H. Phenotypic Investigation of Biofilm Formation and the Prevalence of icaA and icaD Genes in Staphylococcus epidermidis Isolates Iran J Med Microbiol. 2019; 12 (6) :371-381 


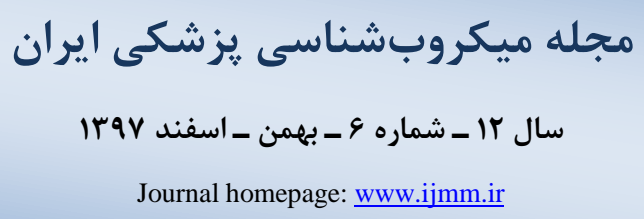

\title{
ارزيابى فنوتيِي تشكيل بيوفيلم و تعيين حضور زنهاى icaA و icaD در جدايههاى بالينى استافيلوكوكوس إيبلرمبيديس
}

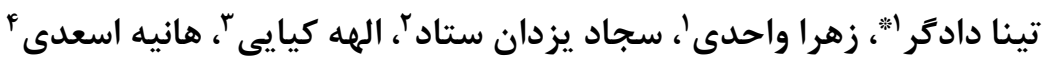

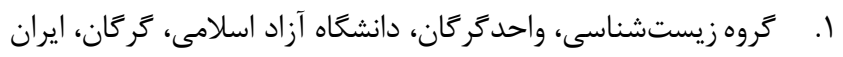

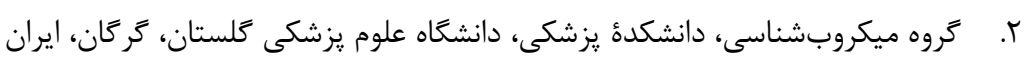

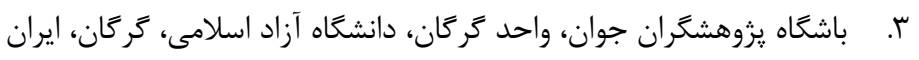

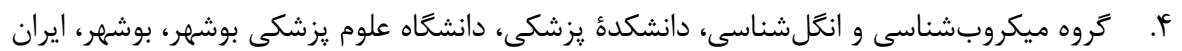

\section{קיكيله}

زمينه و هدف: مهمهرين فاكتور در بيمارىزايى/ستافيلوكوكوس /بيدرميديس توانايى تشكيل بيوفيلم است. شناسايى سويههاى

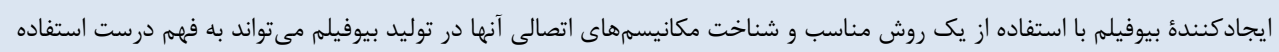

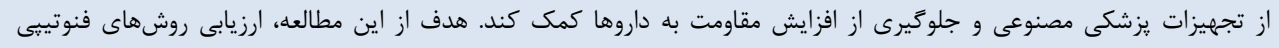

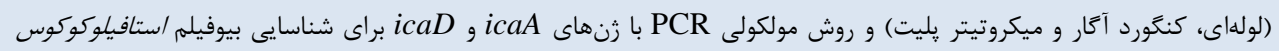

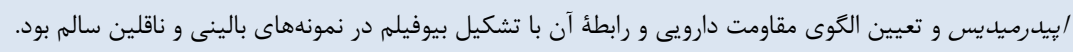

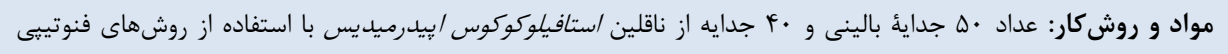

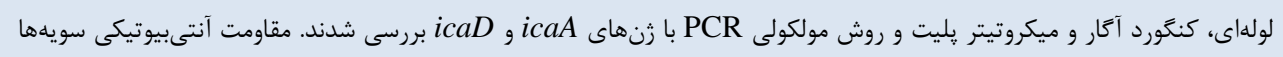

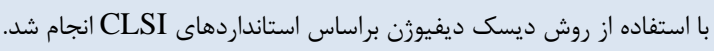

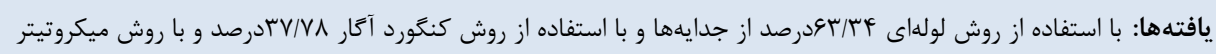

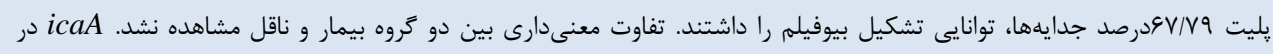

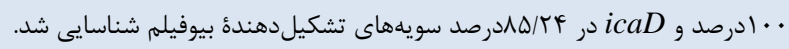

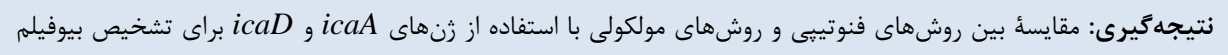

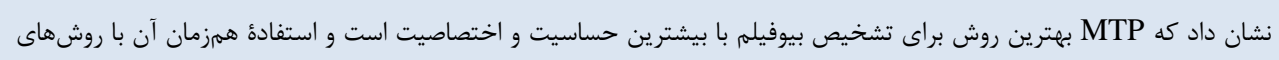
مولكولى توصيه مىشود. كلمات كليدى: استافيلوكوكوس/بيدرميديس، بيوفيلم، مقاومت آنتىبيوتيكى، PCR

اطلاعات مقاله

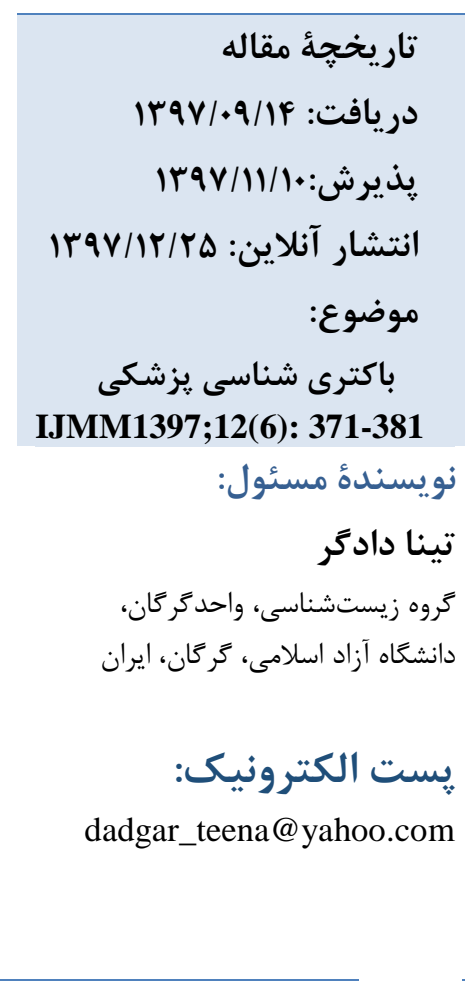

مقام

عفونتهاى بيمارستانى است. عامل مهمر و كليدى در بيمارىزايى

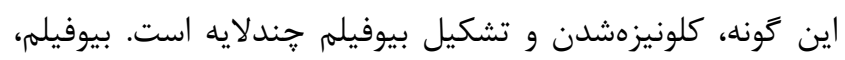

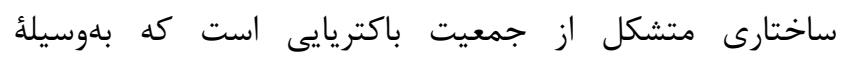

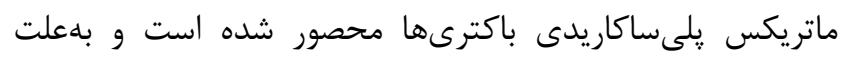

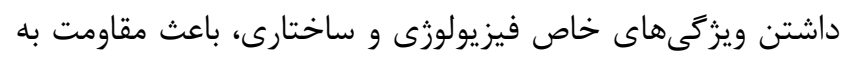

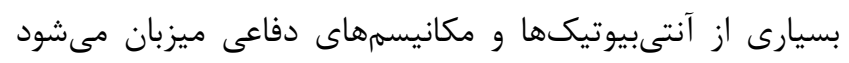

استافيلوكوك هاى كواگولاز منفى (CoNS) فراوانترين فلور

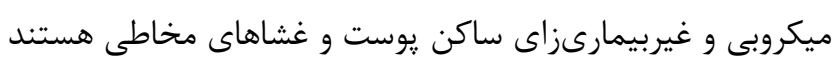

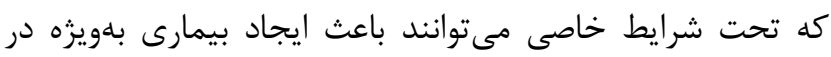

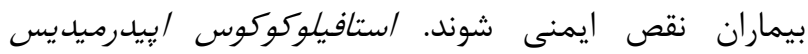

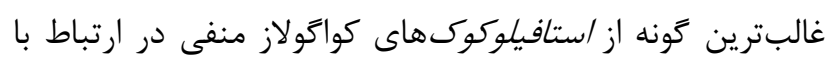

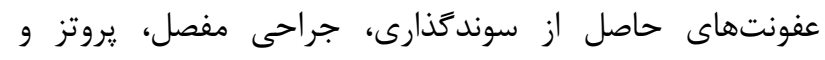




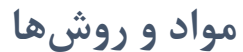

\section{جمع آورى و شناسايى سويههاى باكتريايى}

F• تعداد •و نمونه /ستافيلوكوكوس / بيدرميديس، شامل

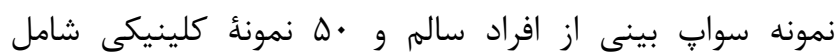

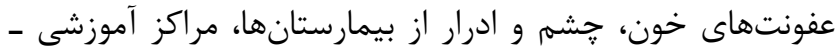

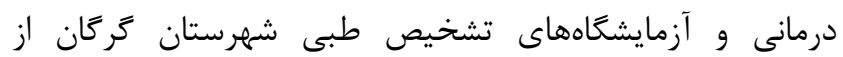

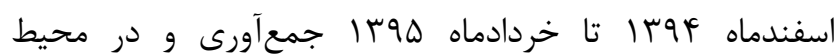
مانيتول سالت آكار (شركت مرك، آلمان) كشت داده و بهمدت

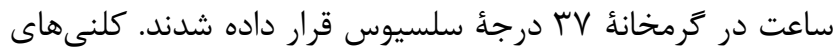
سفيدرنغ و مانيتول منفى براى بررسىهاى بيشتر خالصسازى دارئه

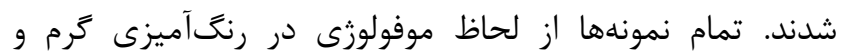

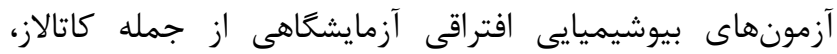

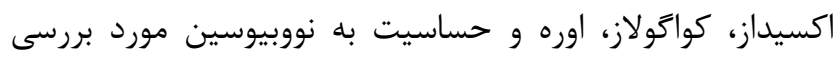

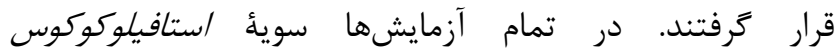

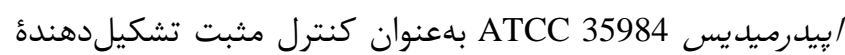
بيوفيلم و /ستافيلوكوكوس /بيدرميديس ATCC 12228 بلهنوميدوان كنترل منفى استفاده شدند.

بررسى فنوتيبى توليد بيوفيلم در جدايهاى استافيلوكوكوس / بيدرميديس لروسيى براى بررسى توانايى تشكيل بيوفيلم سويهها از دو روش

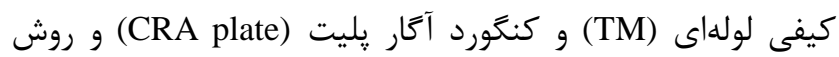
كمّى صفحة كشت بافت (TCP) استفاده شد.

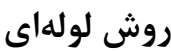

در اين روش يك لوٍ ير باكترى از كشت أTساعته باكترى

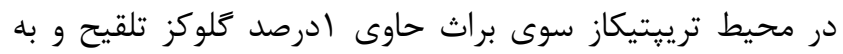

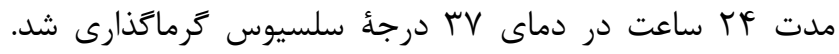

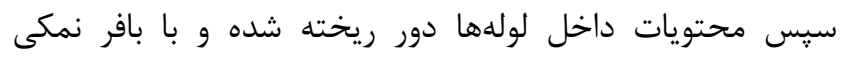

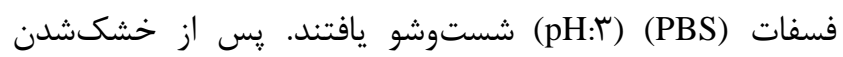

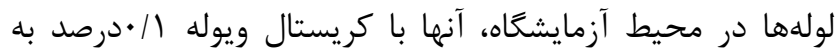

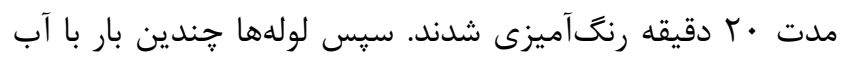

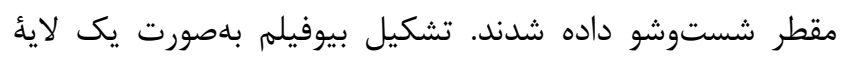
رنگگرفته روى سطح داخلى ديوارئ لوله مشاهده شد كه ميزان

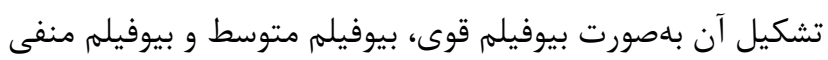
كزارش شد (•) - (1).
(1). تشكيل بيوفيلم در دو مرحله انجام مىشود: اتصال اولئ /ستافيلوكوكوس / ييدرميديس به ماتريكس يروتئينى كه در در وسايل

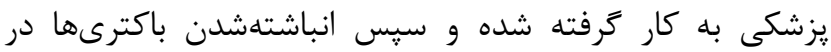
لايههاى مختلف و تشكيل كَليكوكاليكس كه منجر به تشكيل بنديل بيوفيلم بالغ مىشود. يلىساكاريد خارج سلولى (PIA) بهعنوان عامل اصلى در اتصالات بين سلولى بلمنظظور تشكيل بيوفيلم

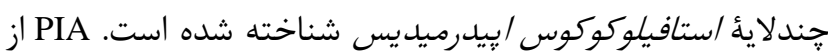

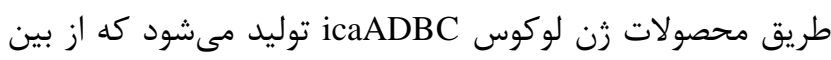

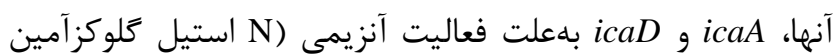
ترانسفراز) نقش مههمرى در تشكيل بيوفيلم ناشى از اين باكترى

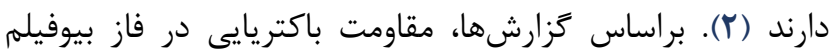

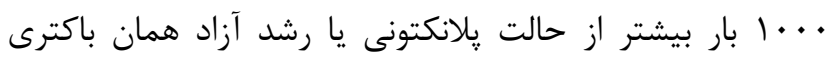
است. جندين مكانيسم در ايجاد اين مقاومت نقش دارند. اولين مكانيسم مربوط به ماتريكس يلىساكاريدى است كه با ايجاد يك إنى إنى

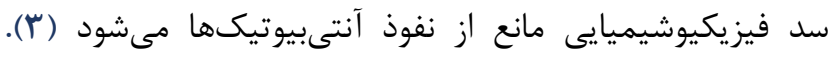
دومين فرضيه در رابطه با مقاومت باكتريايى در مرحلئ بيوفيلمى، مربوط به سطح קايين فعاليت متابوليكى باكترىها در بيوفيلم

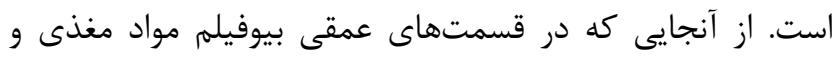
اكسيزن به مقدار كمترى در دسترس باكترى قرار مى گيرد، تكثير و رشد باكتريايى متوقف مىشود يا در سطح بايينى انجام مى

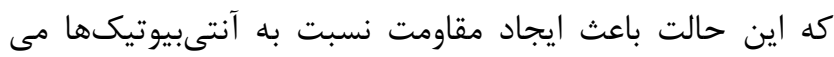

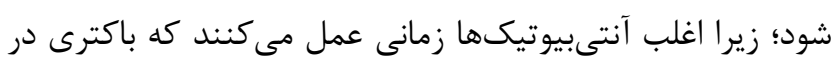

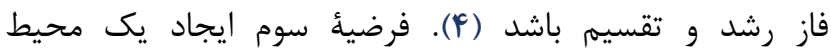
شيميايى تغييريافته درون بيوفيلم است؛ مثلا توليد محصولات

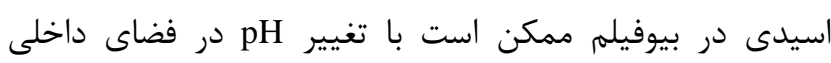
بيوفيلم همراه بوده و باعث تغيير در عملكرد آنتىبيوتيك شود (ه، دئ 9). روشهاى مختلفى براى بررسى توانايى تشكيل بيوفيلم توسط

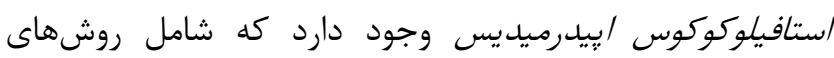
كيفى لولهاى (Tube method)، كنكورد آكار يليت (Congo Red) Agar)

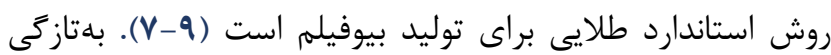

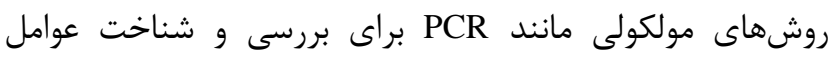
زنتيكى دخيل در تشكيل بيوفيلم استفاده شده است. هدف از اين بررسى حضور زنهاى icaA و icaD در سويههاى /ستافيلوكوكوس دئس

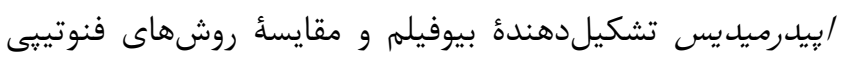
براى تشخيص و بررسى توانايى تشكيل TCP و CRA ،TM بيوفيلم در سويههاى جداشده از بيماران و افراد ناقل سالم در تراني

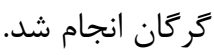


شده و پس از له دقيقه رنخ با آبمقطر شسته شد. يس از خشك آنس

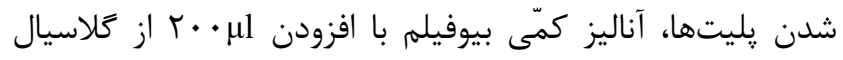

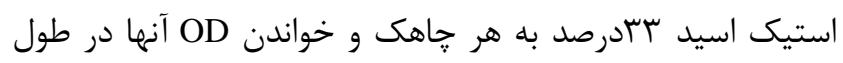

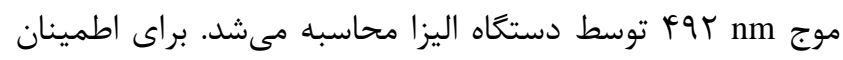

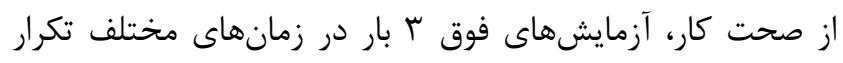

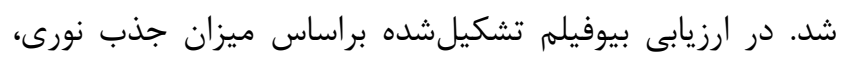

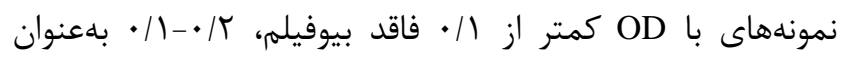

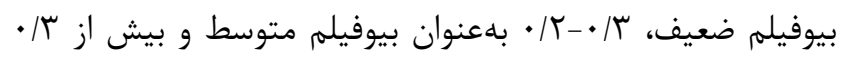

بلهنوان بيوفيلم قوى در نظر گرفته شدند (^).

\section{آزمون PCR براى رديابى زنهاى icaA و icaD}

بلمنظور استخراج ماده زنومى سويههاى توليدكنندة بيوفيلم

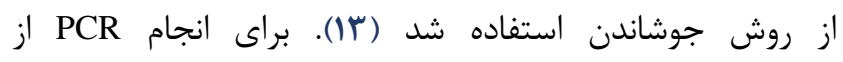

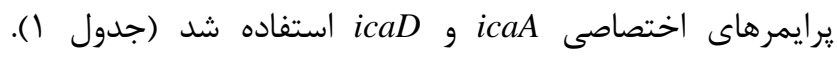

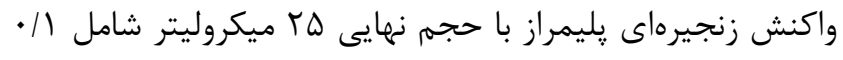

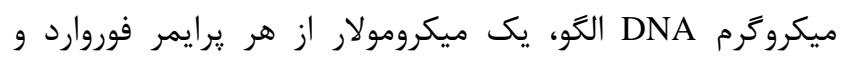

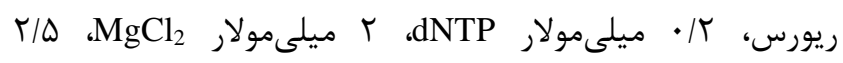

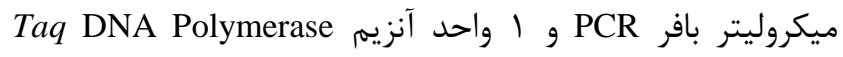

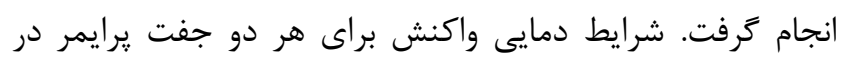

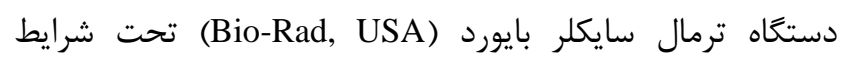

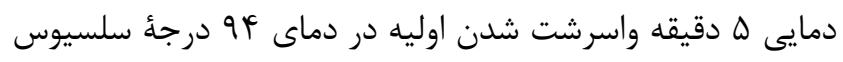

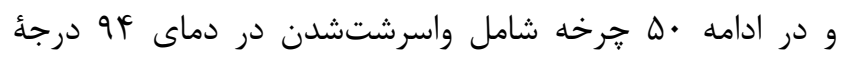

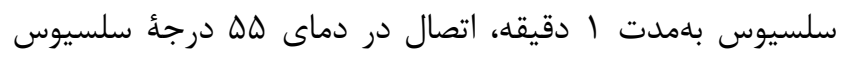

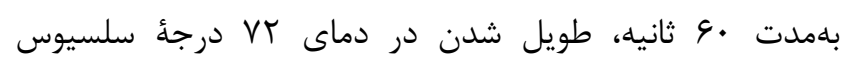

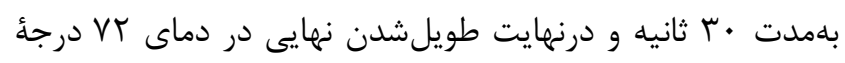

سلسيوس بdمدت يك دقيقه انجام گرفت (If).

\section{روش كنغورد آكار يليت}

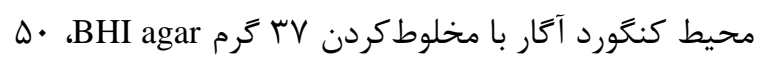

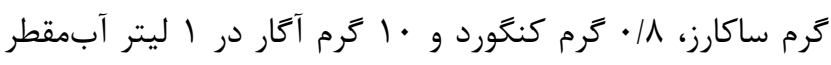

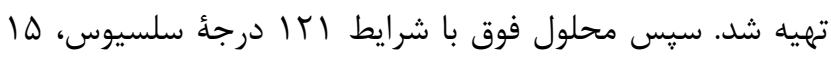

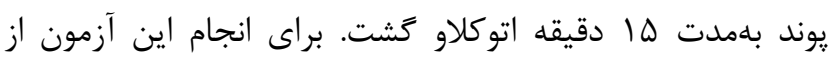

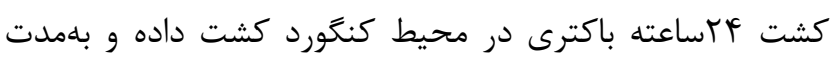

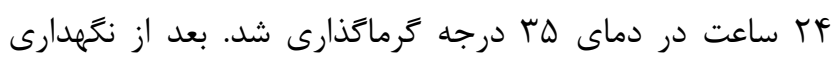

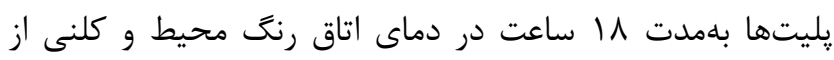

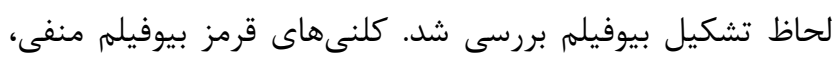
كلنىهاى قرمز روى زمينٔه محيط سياه بيوفيلم + (بيوفيلم

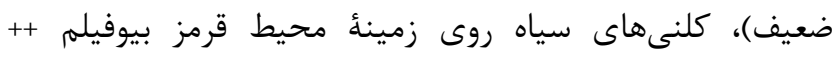

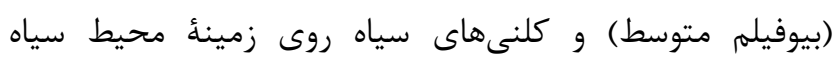
بيوفيلم +++ (بيوفيلمم قوى) ارزيابى شدند (II).

\section{روش ميكروتيتر يليت}

براى بررسى كمّى توانايى تشكيل ايزولهها، اين روش به كار

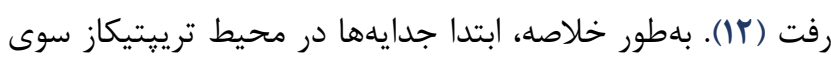

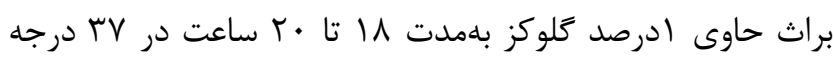

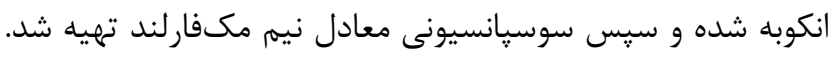

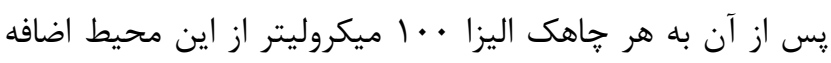

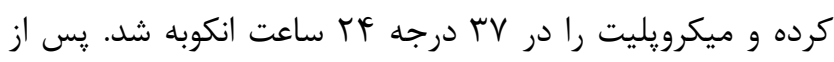

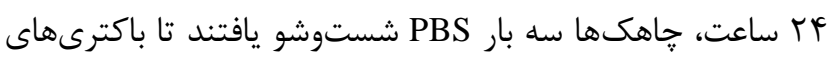

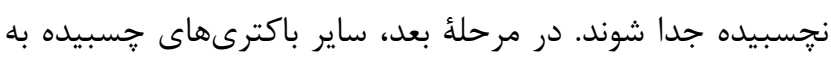

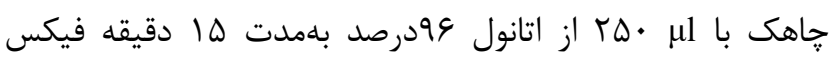

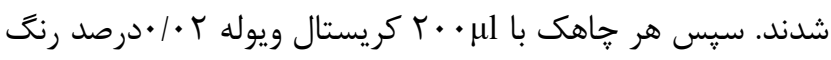

جدول ا. مشخصات يرايمرهاى استفادهده در مطالعه

\begin{tabular}{|c|c|}
\hline يرايمر & توالى ('3-3') \\
\hline$i c a A$ & $\begin{array}{l}\text { F: TCT CTT GCA GGA GCA } \\
\text { R: TCA GGC ACT AAC ATC }\end{array}$ \\
\hline$i c a D$ & $\begin{array}{l}\text { F: ATG GTC AAG } \\
\text { R: CGT GTT TTC AA }\end{array}$ \\
\hline \multicolumn{2}{|c|}{ 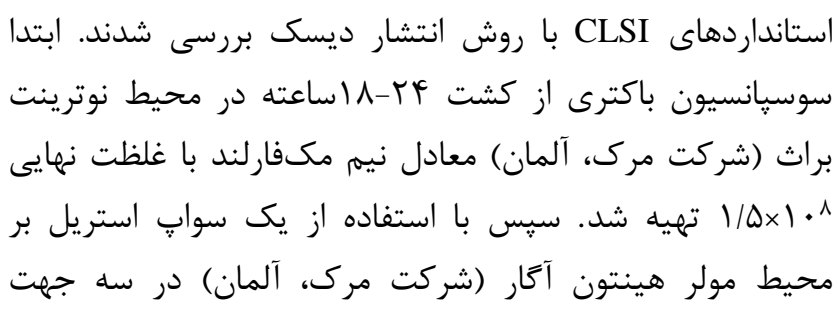 } \\
\hline
\end{tabular}

اندازه قطعه (جفت باز bp)

111

194

(If)

\section{تعيين حساسيت باكترى به آنتىبيوتيك}

سويههاى /ستافيلوكوكوس /بيدرميديس از نظر مقاومت به

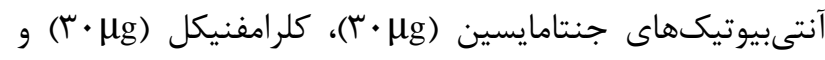

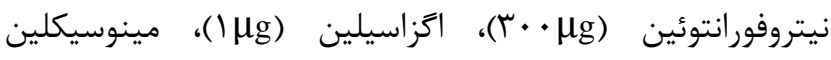

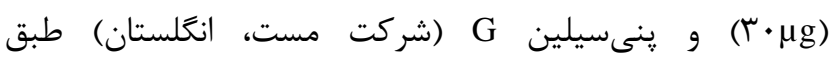


بلهدستآمده از نمونهها و نتايج ارزيابىها در نرمافزار SPSS-16

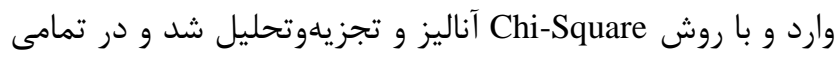

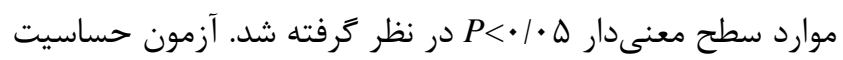

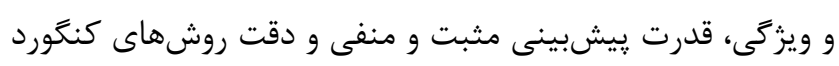

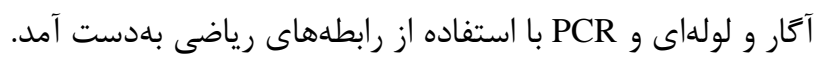

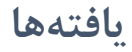

مشخصات جدايههاى بررسى بافهده با توجه به نوع نمونه و

جنسيت بيماران در جدول بار ارائه شده است.
بلهورت متراكم كشت داده شد. درنهايت، ديسكهاى آنتى

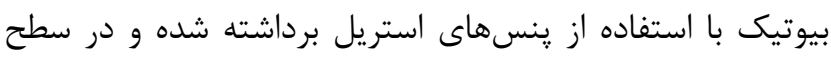

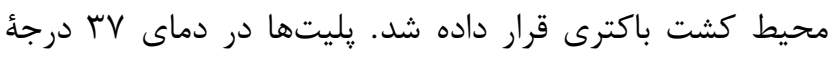

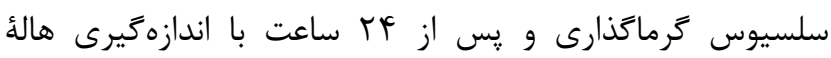

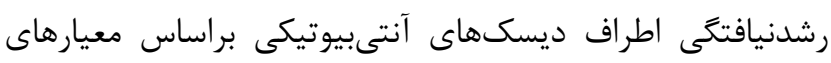

CLSI

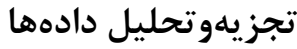

در اين تحقيق از آمارهاى توصيفى ميانگين، انحرافمعيار و

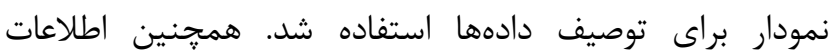

جدول شماره r. مشخصات مربوط به سن، جنس و درصد يراكنش نوع نمونهها در بين افراد ناقل و بيمار

\begin{tabular}{|c|c|c|c|}
\hline بيمار (درصد) & ناقل(درصد) & & اطلاعات بيماران \\
\hline$(\Delta \cdot) \Gamma \Delta$ & $(r \Delta) \mid F$ & مرد & \multirow{2}{*}{ جنس } \\
\hline$(\Delta \cdot) \Gamma \Delta$ & $(\varepsilon \Delta) \Gamma \varepsilon$ & زن & \\
\hline . & $(1 \cdot \cdot)^{k}$. & بينى & \multirow{4}{*}{ نوع نمونه } \\
\hline$(\Delta \varepsilon) \Gamma \varepsilon$ & · & ادرار & \\
\hline$\left(Y^{G} T\right) Y$ I & . & خون & \\
\hline$(r))$ & . & جشم & \\
\hline
\end{tabular}

\section{ارزيابى تشكيل بيوفيلم با روش كنگَورد آتار}

نتايج حاصل از بررسى كيفى تشكيل بيوفيلم در روش

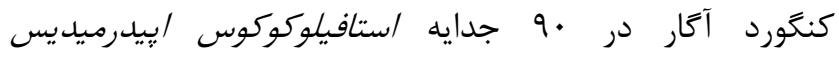

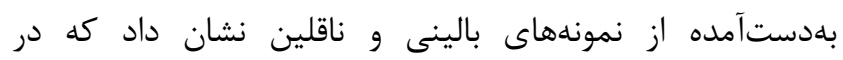

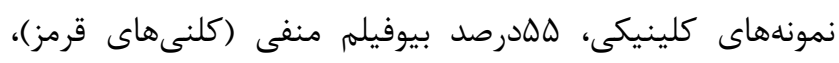
Vادرصد بيوفيلم ضعيف (كلنىهاى قرمز روى زمينهٔ محيط سياه)،

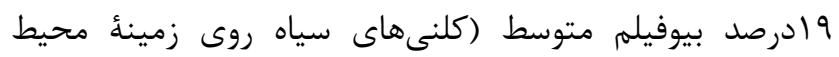

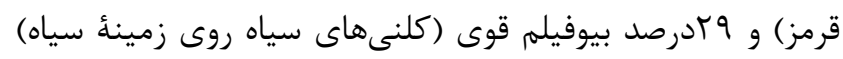

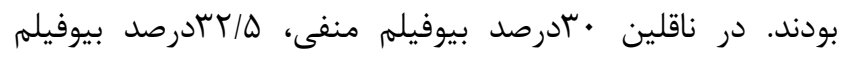

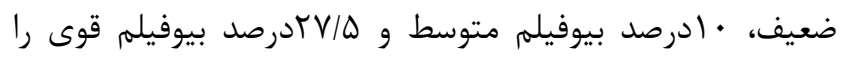

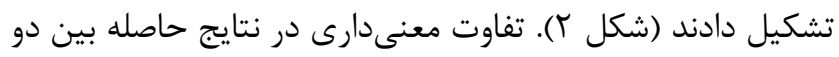

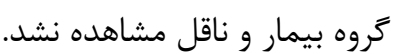

\section{ارزيابى تشكيل بيوفيلم با روش تست لوله} نتايج حاصل از بررسى كيفى تست لوله در نمونههاى

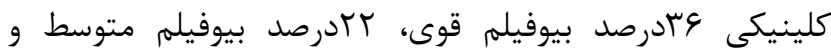

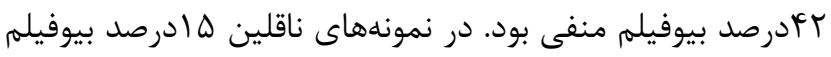

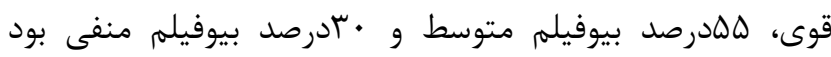
(شكل (). تفاوت معنىدارى بين دو گروه بيمار و ناقل مشاهده

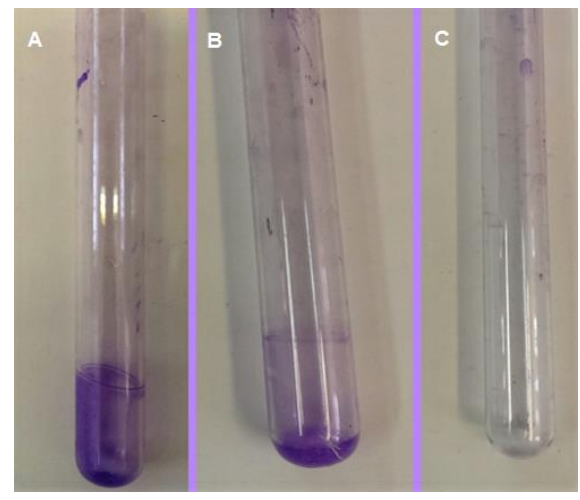

شكل ا. نتايج بيوفيلم در تست لوله. A) بيوفيلم قوى. B) بيوفيلم

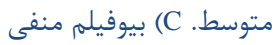


تشكيلدهندة بيوفيلم شناسايى شدند، منفى بود و يك جدايه از

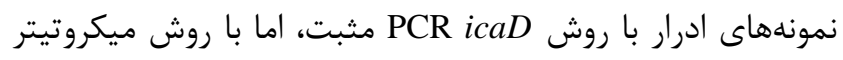

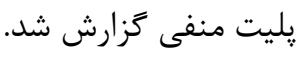

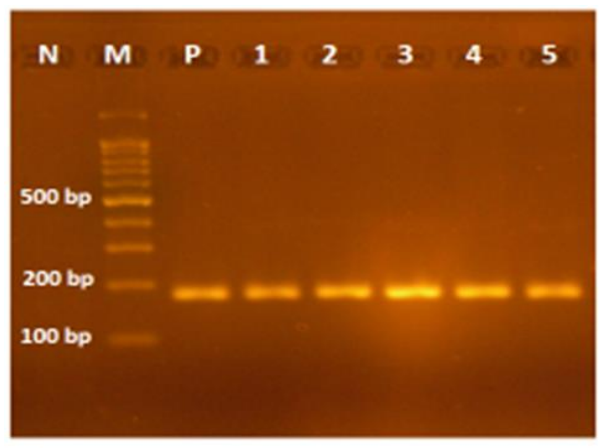

A

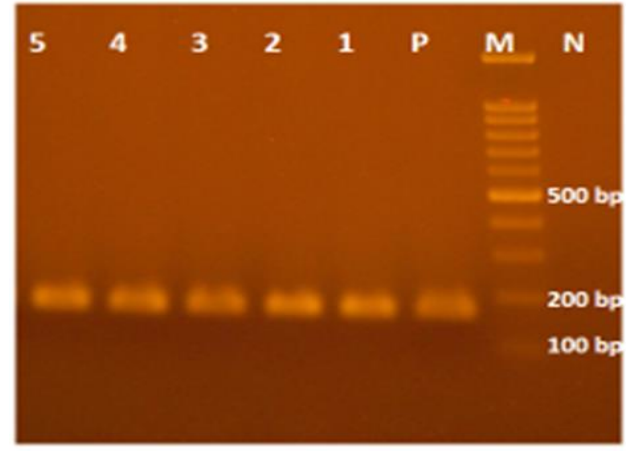

B

شكل fا. شناسايى زن هاى (A) icaA و

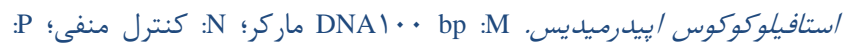

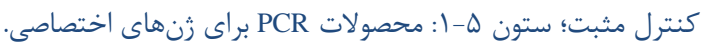

مقايسةُ نتايج تشكيل بيوفيلهم در روشهاى فنوتيبى و

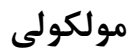

از بين •و نمونه، او جدايه توانايى تشكيل بيوفيلم داشتند

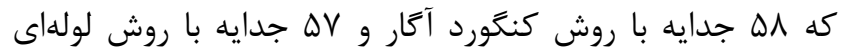
شناسايى شدند. روش MTP بهعنوان استاندارد طلايى براى رون

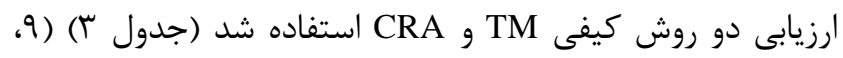

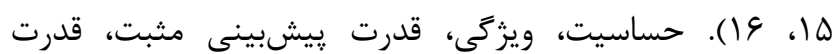

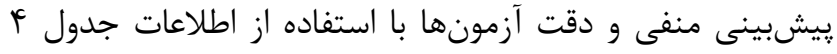

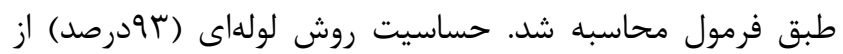

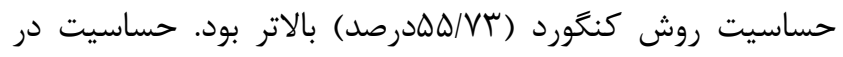
روش PCR با استفاده از زن icaA از دو روش فنوتيبى CRA و

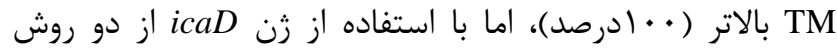

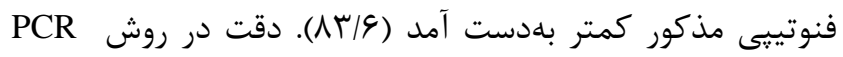
icaA در مقايسه با ساير روشها بيشتر بود (جدول هات هد).

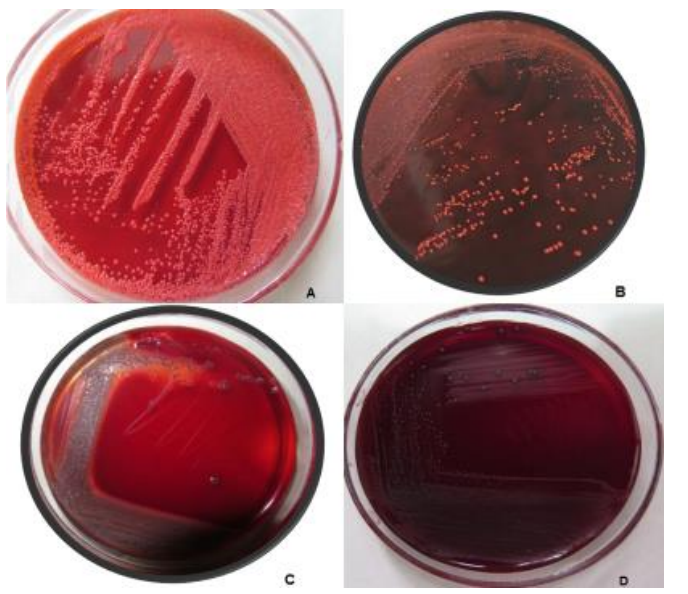

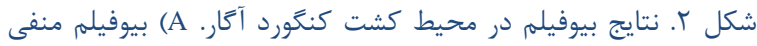

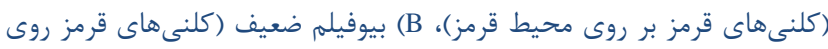

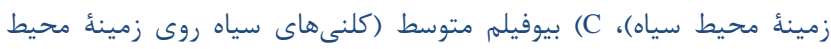
قرمز) و D) بيوفيلهم قوى (كلنىهاى سياه روى زمينأ سياه). ارزيابى تشكيل بيوفيلم با روش ميكروتيتر هليت

نتايج حاصل از بررسى كمّى تشكيل بيوفيلم در جدايههاى بالينى

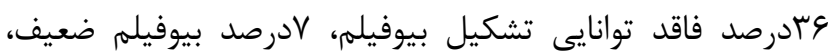
rادرصد بيوفيلم متوسط و F آدرصد بيوفيلم قوى را نشان دادند.

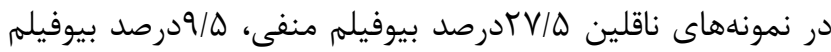

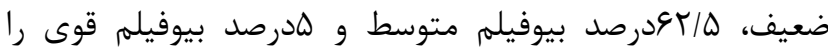
تشكيل دادند (شكل r).

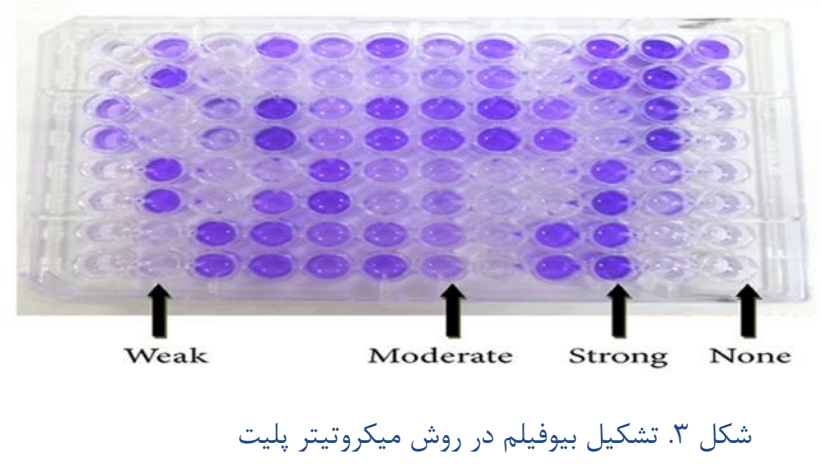

نتايج آزمون PCR براى زن هاى icaA و

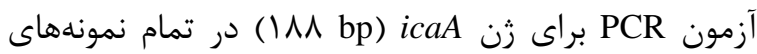

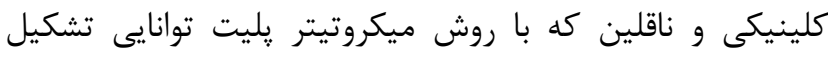

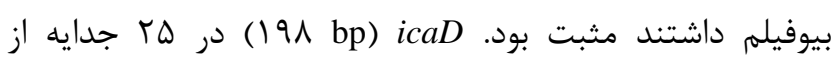

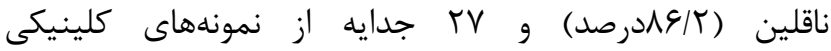

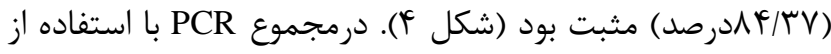

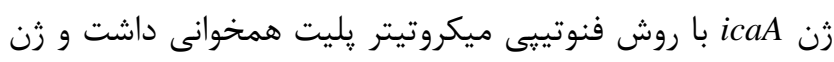

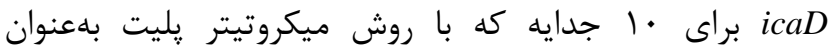


جدول r. مقايسأ نتايج تشكيل بيوفيلمها در روشهاى فنوتيبى و مولكولى

\begin{tabular}{|c|c|c|c|c|c|c|c|c|c|}
\hline \multirow{2}{*}{\multicolumn{2}{|c|}{ تشكيل دهندر زن در بيوفيلم (درصد }} & \multicolumn{6}{|c|}{ تعداد تشكيل بيوفيلم (درصد) } & \multirow{2}{*}{\multicolumn{2}{|c|}{ مشخصات (تعداد) }} \\
\hline & & \multicolumn{2}{|c|}{ لولهاى } & \multicolumn{2}{|c|}{ كنخورد آكار } & \multicolumn{2}{|c|}{ ميكروتيتر يليت } & & \\
\hline$i c a D$ & $i c a A$ & 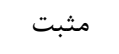 & 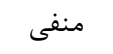 & 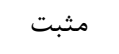 & 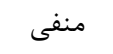 & 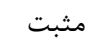 & 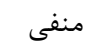 & & \\
\hline $\begin{array}{c}r \Delta \\
(\Lambda \varepsilon / T)\end{array}$ & $\begin{array}{c}r q \\
(1 \cdots)\end{array}$ & $\begin{array}{l}r \wedge \\
(r \cdot)\end{array}$ & $(r \cdot)$ & $\begin{array}{c}10 \\
(T V / Q)\end{array}$ & $\begin{array}{l}r \Delta \\
(\varepsilon Y / \Delta)\end{array}$ & $\begin{array}{c}r q \\
(V r / \Delta)\end{array}$ & $\begin{array}{c}11 \\
(Y V / D)\end{array}$ & بينى (• (f) & ناقل (•) \\
\hline $\begin{array}{c}19 \\
(1 \cdots)\end{array}$ & $\begin{array}{l}10 \\
(1 \cdots)\end{array}$ & $\begin{array}{ll}1 F \\
(\Delta \cdot)\end{array}$ & $\begin{array}{ll}14 \\
(\Delta \cdot)\end{array}$ & $\begin{array}{c}11 \\
(r 9 / r \Lambda)\end{array}$ & $\begin{array}{l}\text { IV } \\
(\varepsilon \cdot / V Y)\end{array}$ & $\begin{array}{c}10 \\
(\Delta / / \Delta \Lambda)\end{array}$ & $\begin{array}{c}(K E / F T) \\
\text { IT }\end{array}$ & ادرار (Y^) & \\
\hline $\begin{array}{l}1 \cdot \\
(\& / / Q)\end{array}$ & $\begin{array}{c}19 \\
(1 \cdots)\end{array}$ & $\begin{array}{c}10 \\
\left(V / / \mathbb{K r}^{\mathrm{N}}\right)\end{array}$ & $\begin{array}{c}q \\
(Y N / \Delta V)\end{array}$ & $\begin{array}{c}\wedge \\
(Y \wedge / \Delta V)\end{array}$ & $\begin{array}{c}(\& g / K t) \\
\text { IT }\end{array}$ & $\begin{array}{c}19 \\
(V 9 / T)\end{array}$ & $\begin{array}{c}\Delta \\
(Y H / \Lambda)\end{array}$ & خون (II) & بيمار (••ه) \\
\hline $\begin{array}{c}1 \\
(1 \cdots)\end{array}$ & $\begin{array}{c}1 \\
(1 \cdots)\end{array}$ & $\cdot$ & $\begin{array}{c}1 \\
(1 \cdots)\end{array}$ & . & $\begin{array}{c}1 \\
(1 \cdots)\end{array}$ & $\begin{array}{c}1 \\
(1 \cdots)\end{array}$ & $\cdot$ & جشم (1) & \\
\hline $\begin{array}{c}\Delta Y \\
(\Lambda \Delta / T F)\end{array}$ & $\begin{array}{c}91 \\
(1 \cdots)\end{array}$ & $\begin{array}{c}\Delta V \\
(\varepsilon r / \mu F)\end{array}$ & $\begin{array}{c}\text { r } \\
(\Psi 9 \mid 99)\end{array}$ & $\begin{array}{c}r F \\
(r V / V \wedge)\end{array}$ & $\begin{array}{c}\Delta G \\
(G T / T Y)\end{array}$ & $\begin{array}{c}91 \\
(9 V / V 9)\end{array}$ & $\begin{array}{c}r q \\
(Y T / Y T)\end{array}$ & 9 . & مجموع (•() \\
\hline
\end{tabular}

جدول Y. تشكيل بيوفيلم با استفاده از روشهاى TCR و TCP،CRA TM

\begin{tabular}{|c|c|c|c|c|c|c|c|c|c|}
\hline \multicolumn{2}{|c|}{ PCR icaD } & \multicolumn{2}{|c|}{ PCR icaA } & \multicolumn{2}{|c|}{ لولهاى } & \multicolumn{2}{|c|}{ كنكَورد آكار } & \multirow{2}{*}{\multicolumn{2}{|c|}{ روش آزمايش }} \\
\hline منفى & مثبت & منفى & مثبت & منفى & مثبت & منفى & مثبت & & \\
\hline $1 \cdot$ & DI & $\cdot$ & 91 & f & $\Delta V$ & TV & re & مثبت & ميكروتيتر \\
\hline rᄉ & 1 & rq & · & rq & · & rq & · & منفى & يليت \\
\hline
\end{tabular}

جدول ه. آناليز آمارى روشهاى كنَّورد آَار و لولهاى در مقايسه با روش استاندارد طلايى ميكروتيتر پيليت براى تشخيص تشكيل بيوفيلم

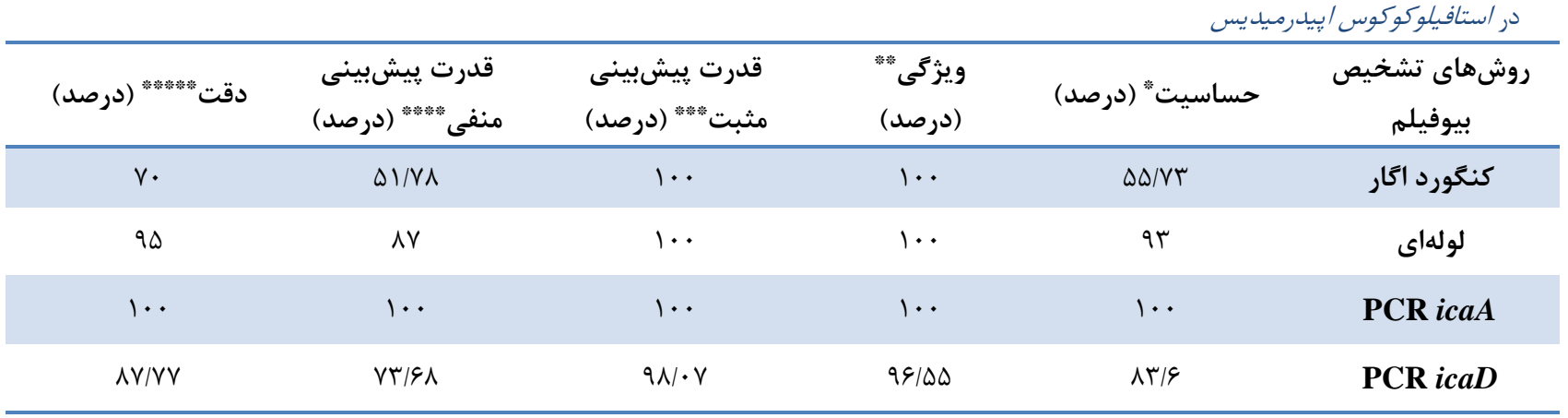

* Sensitivity, $*$ Specificity, $* * *$ Positive Predictive Power, $* * * *$ Negative Predictive Power, $* * * * *$ Accuracy 
ميزان توليد بيوفيلم در روش ميكروتيتر يليت

$$
\text { براساس مقاومت دارويى توليد بيوفيلم }
$$

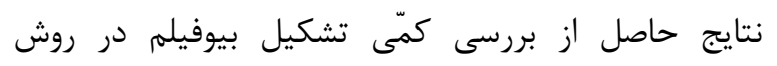

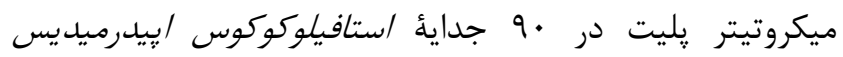

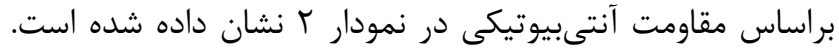

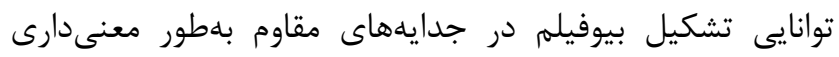

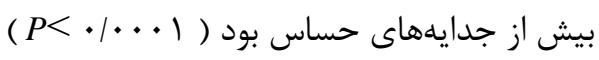

\section{مقاومت جدايههاى /ستافيلوكوكوس /بيدرميديس به آنتى بيوتيكهاى مور دمطالعه}

مقايسٔ درصد فراوانى سويههاى مقاوم به آنتىبيوتيكهاى

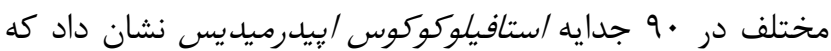

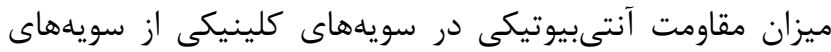
افراد ناقل سالم بيشتر بوده است (نمودار ().

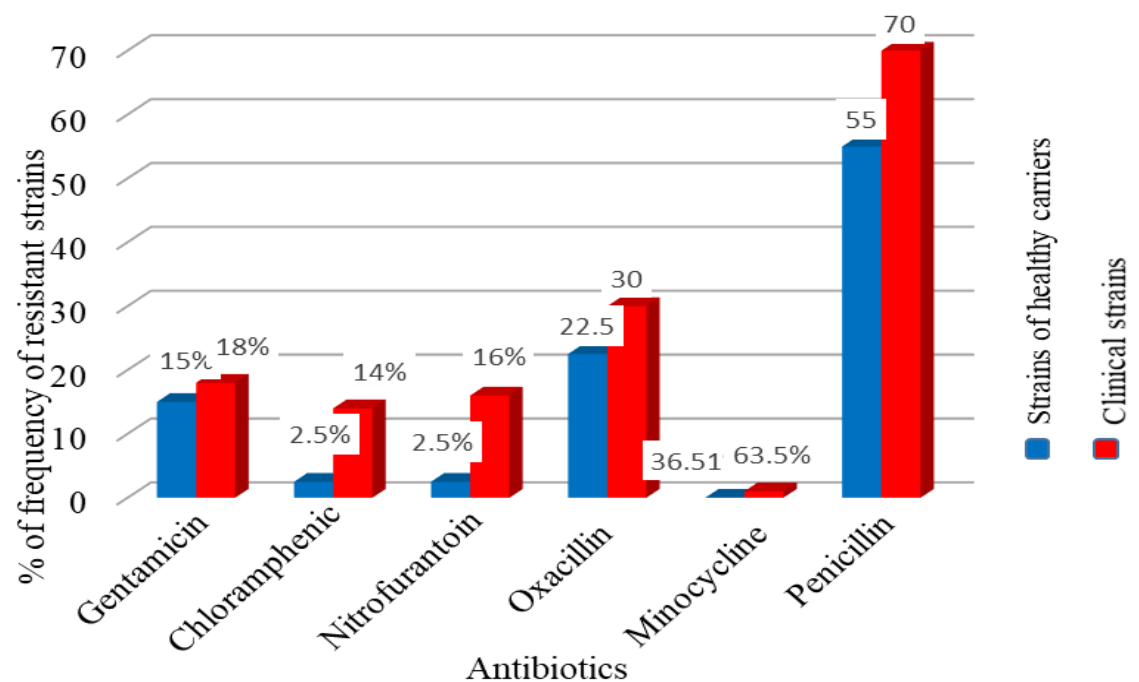

نمودار ا. درصد فراوانى سويههاى /ستافيلوكوكوس /بيدرميديس مقاوم به آنتىبيوتيك در سويههاى كلينيكى و سويههاى جداشده از افراد سالم

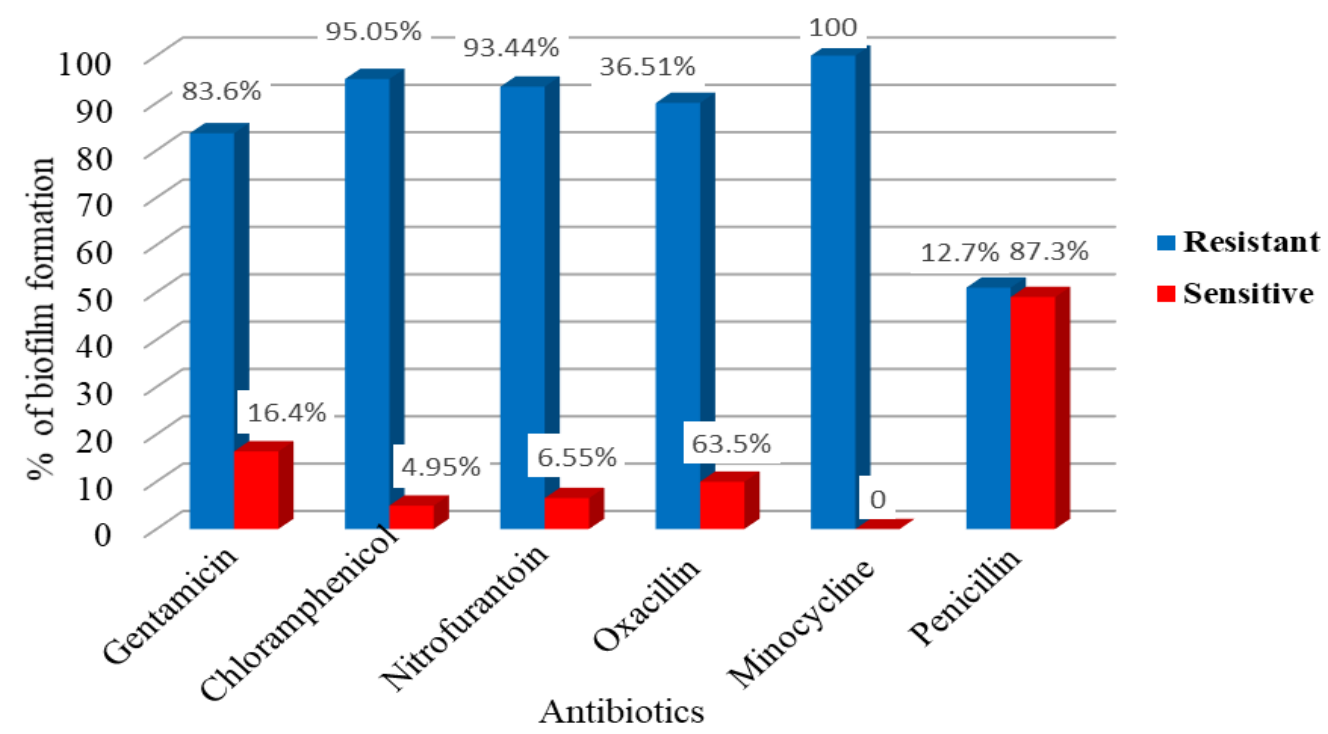

نمودار r. مقايسٔ مقاومت و حساسيت دارويى با ميزان توليد بيوفيلم براساس روش ميكروتيتر پِليت 


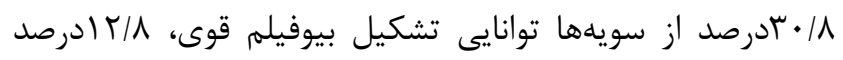

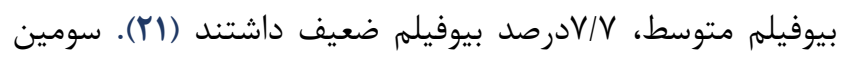

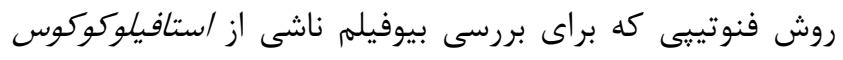

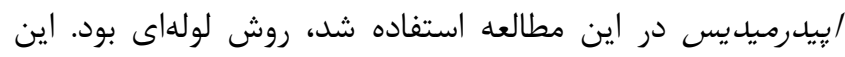

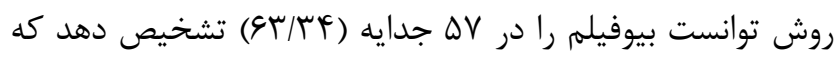

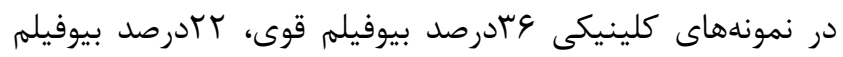

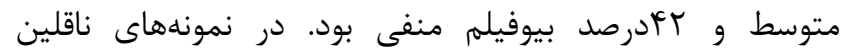

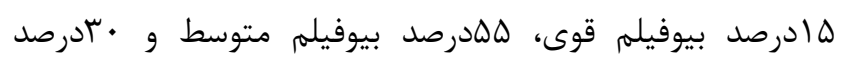

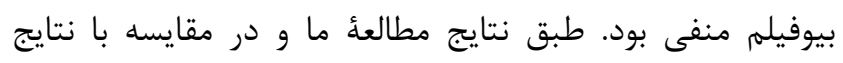

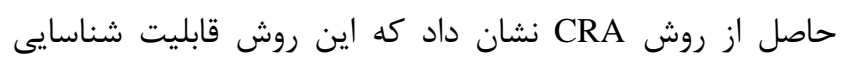

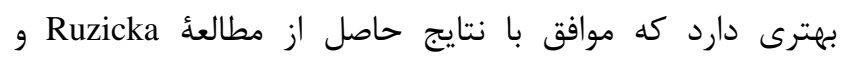

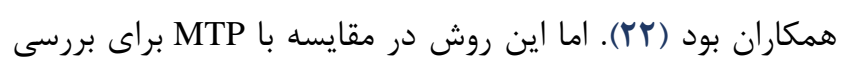

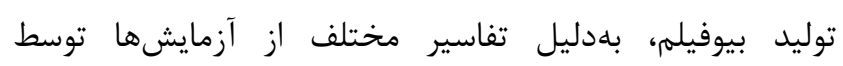

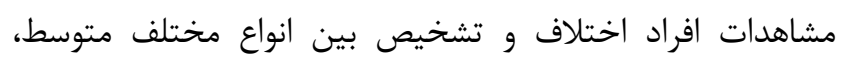

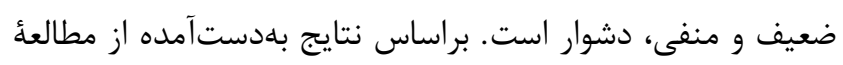
ما و مطالعات كذشته، روش

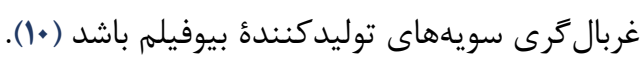

در اين مطالعه، براى بررسى بيوفيلم از روش مولكولى دCR

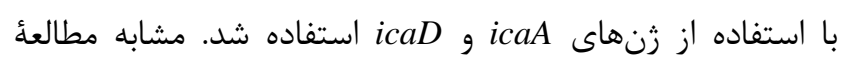
و و همكاران (Yr) Gad

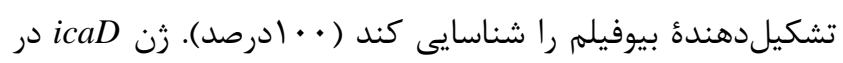

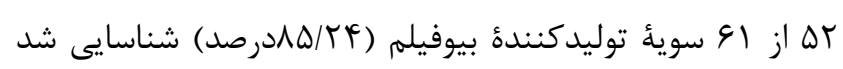

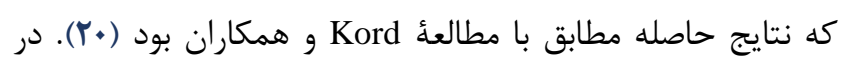

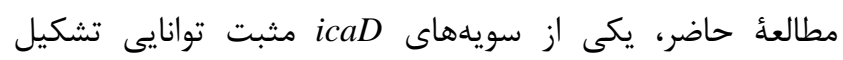

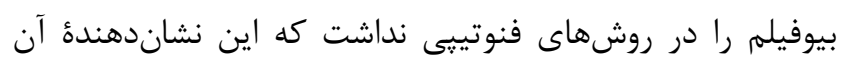

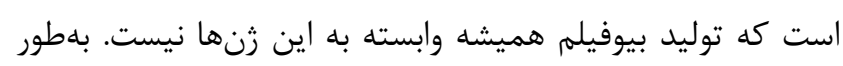

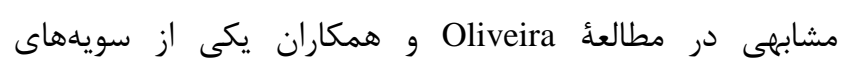

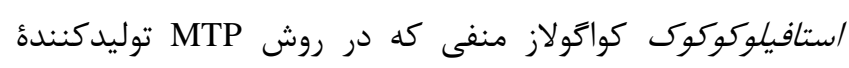

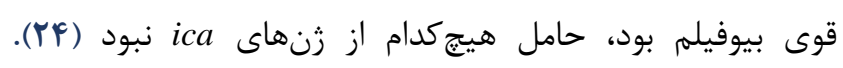

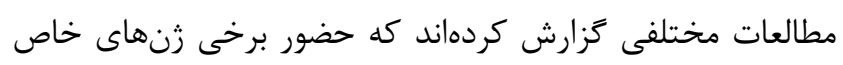

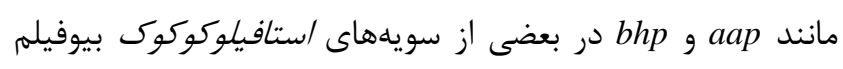

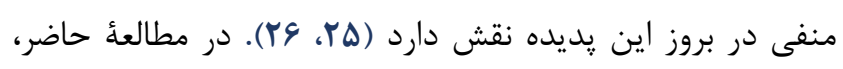

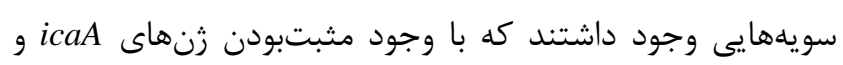

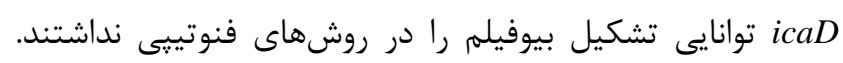

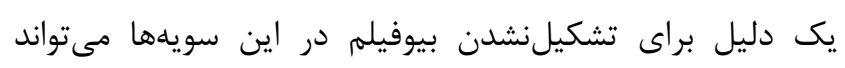

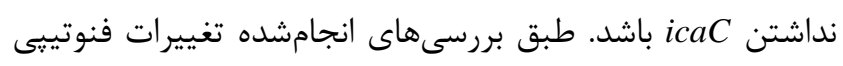

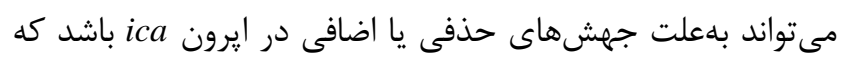

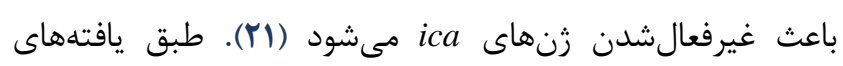

\section{بحث و نتيجه كيرى}

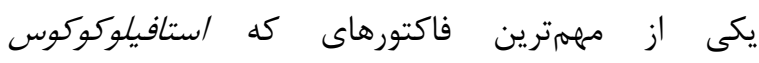
إبيدرميديس را به يك ياتوزن مهرم بيمارستانى تبديل كرده است،

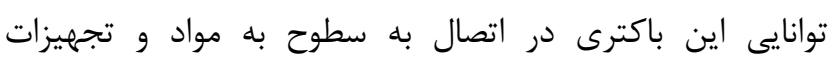

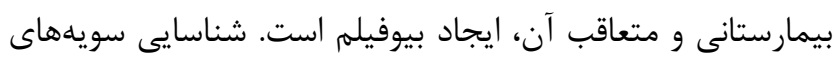

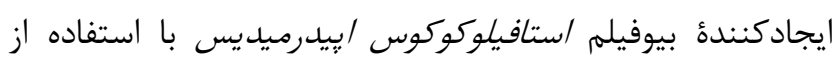

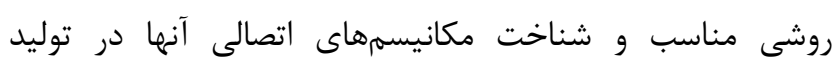

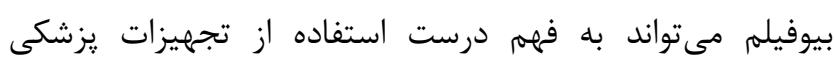
مصنوعى و جلوكيرى از افزايش مقاومت به دارون داروها كمك كن كند.

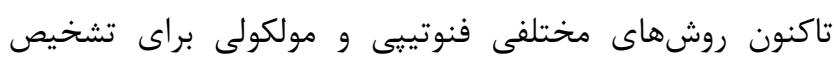

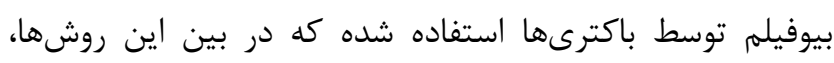

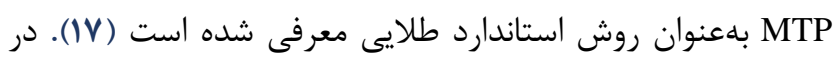

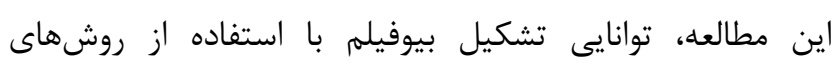

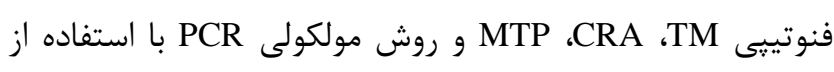

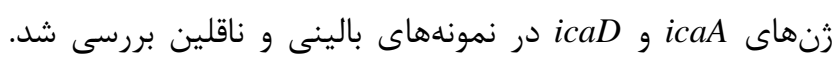

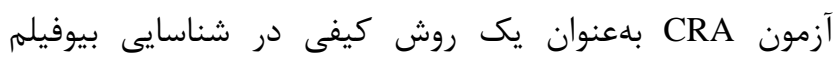

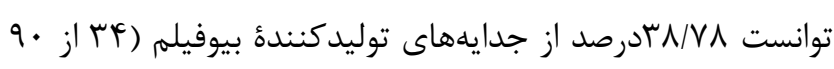

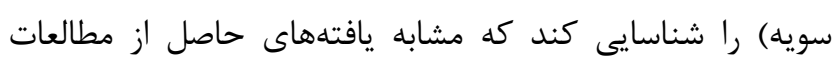
Arslan

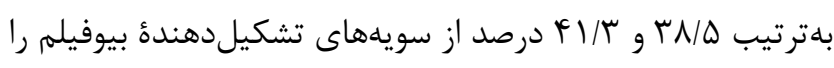

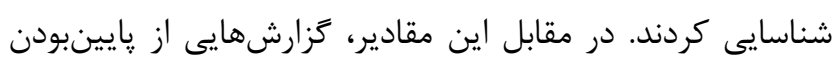

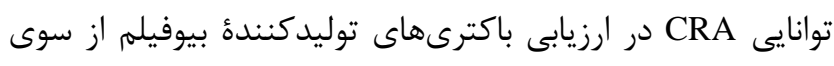
Kord

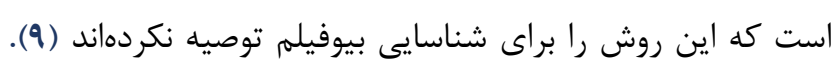

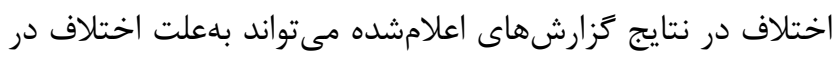

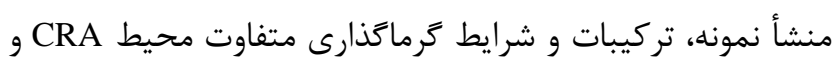
تفاسير مختلف از رنغ كلنى و محيط باشد. روش

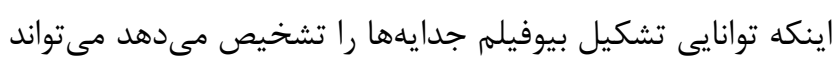

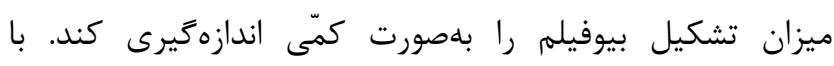

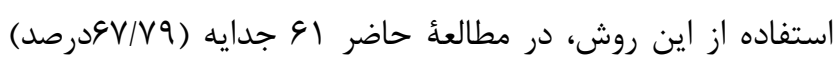

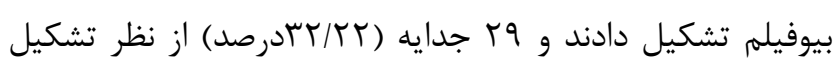

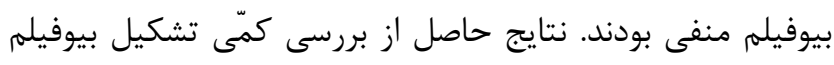

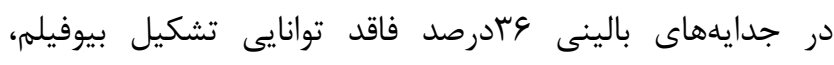

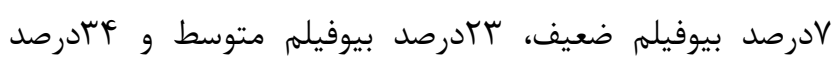

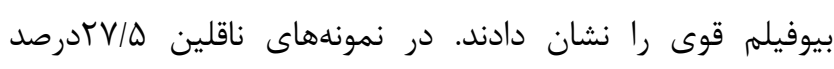

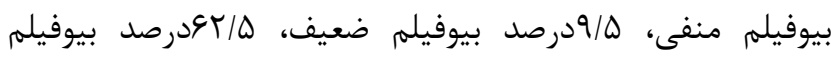

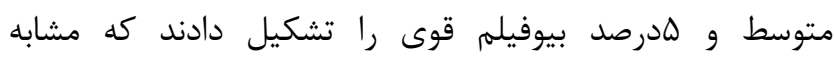
يافتههاى مطالعه NTA El-Khier و همكاران بود. در اين مطالعه 


$$
\begin{aligned}
& \text { ديسك ديفيوزن بررسى شد، ميزان مقاومت دارويى در سويههاى }
\end{aligned}
$$

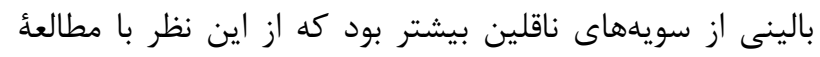

$$
\begin{aligned}
& \text { Kozitskaya } \\
& \text { توليد بيوفيلم براساس مقاومت دارويى نشان داد كه سويههاى } \\
& \text { مقاوم به آنتىبيوتيك توانايى بيشترى در توليد بيوفيلم دارند. } \\
& \text { مطالعة حاضر با مقايسه بين روشهاى فنوتييى و روشهاى } \\
& \text { مولكولى با استفاده از زنهاى icaA و أicaD براى تشخيص بيوفيلم }
\end{aligned}
$$

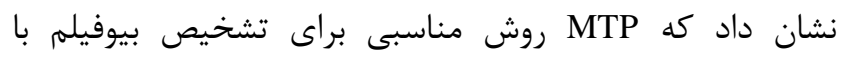

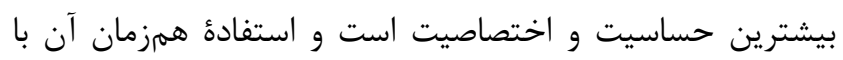

$$
\begin{aligned}
& \text { روشهاى مولكولى توصيه مىشود. } \\
& \text { سياسخز ارى } \\
& \text { نويسندكان اين مقاله از همكارى دانشكاه آزاد اسلامى، }
\end{aligned}
$$

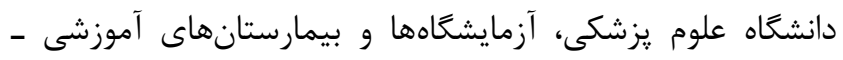

$$
\begin{aligned}
& \text { درمانى شهرستان گركان كمال تشكر و قدردانى را دارنداندان } \\
& \text { تعارض منافع } \\
& \text { بين نويسندًان تعارض در منافع گزارش نشده است. }
\end{aligned}
$$

\section{References}

1. Otto M. Staphylococcus epidermidisthe'accidental'pathogen. Nat Rev Microbiol. 2009; 7(8): 555. https://doi.org/10.1038/nrmicro2182

2. Mack D, Becker P, Chatterjee I, Dobinsky S, Knobloch JK, Peters G, Rohde H, Herrmann M. Mechanisms of biofilm formation in Staphylococcus epidermidis and Staphylococcus aureus: functional molecules, regulatory circuits, and adaptive responses. Int J Med Microbiol. 2004; 294(2-3): 203-12. https://doi.org/10.1016/j.ijmm.2004.06.015

3. Ciofu O, Mandsberg LF, Wang H, Høiby N. Phenotypes selected during chronic lung infection in cystic fibrosis patients: implications for the treatment of Pseudomonas aeruginosa biofilm infections. FEMS Immunol Med Microbiol. 2012; 65(2): 215-25. https://doi.org/10.1111/j.1574-695X.2012.00983.X

4. Høiby N, Bjarnsholt T, Givskov M, Molin S, Ciofu O. Antibiotic resistance of bacterial biofilms. Int $\mathrm{J}$ Antimicrob Agents. $\quad 2010 ; \quad 35(4): \quad 322-32$. https://doi.org/10.1016/j.ijantimicag.2009.12.011

5. Bazzaz BS, Khameneh B, Zarei H, Golmohammadzadeh S. Antibacterial efficacy of rifampin loaded solid lipid nanoparticles against Staphylococcus epidermidis biofilm. Microbial
Ziebuhr غيرفعالسازى زن icaA و فقدان تشكيل بيوفيلم در روشهاى فنوتييى است (YV). مقايسُٔ بين روشهاى فنوتييى و روشهاى رنهاي مولكولى با استفاده از زن هاى icaA و icaD براى تشخيص بيوفيلم در مطالعه ما نشان داد كه MTP بهترين روش براى تشخيص بيوفيلم با بيشترين حساسيت و اختصاصيت است و استفاده همزمان آن با روشهاى مولكولى توصيه مىشود. بئنسئ

از بين · · جدائه /ستافيلوكوكوس / بيدرميديس، وج جدايه

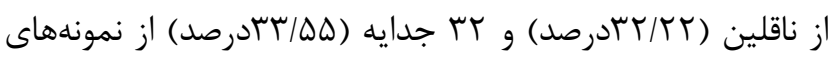
كلينيكى توانايى تشكيل بيوفيلم را داشتند كه با مطالعات كذشته

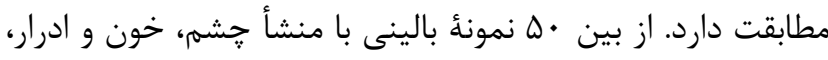

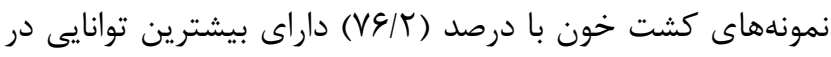

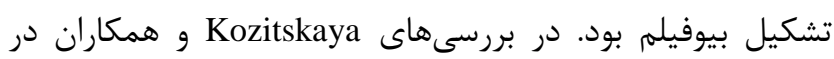
آلمان روى /ستافيلوكوكوس / بيدرميديس، مشخص شد كه از بين

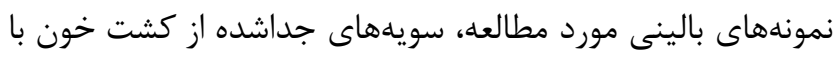

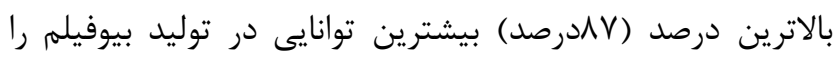

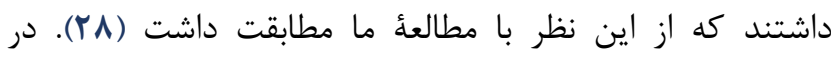

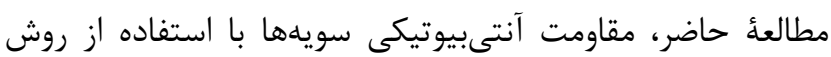
pathogenesis.
2016
93:
$137-44$.

https://doi.org/10.1016/j.micpath.2015.11.031

6. Costerton JW, Stewart PS, Greenberg EP. Bacterial biofilms: a common cause of persistent infections. Science. 1999; 284(5418): 1318-22. https://doi.org/10.1126/science.284.5418.1318

7. De Silva GD, Kantzanou M, Justice A, Massey RC, Wilkinson AR, Day NP, Peacock SJ. The ica operon and biofilm production in coagulase-negative staphylococci associated with carriage and disease in a neonatal intensive care unit. Journal of clinical microbiology. $\quad 2002 ; \quad 40(2)$ : $\quad 382-8$. https://doi.org/10.1128/JCM.40.02.382-388.2002

8. Christensen GD, Simpson WA, Younger JJ, Baddour LM, Barrett FF, Melton DM, Beachey EH. Adherence of coagulase-negative staphylococci to plastic tissue culture plates: a quantitative model for the adherence of staphylococci to medical devices. Journal of clinical microbiology. 1985; 22(6): 996-1006.

9. Mathur T, Singhal S, Khan S, Upadhyay DJ, Fatma T, Rattan A. Detection of biofilm formation among the clinical isolates of staphylococci: an evaluation of three different screening methods. Indian J Med Microbiol. 2006; 24(1): 25. https://doi.org/10.4103/02550857.19890 
10. Christensen GD, Simpson WA, Bisno AL, Beachey EH. Adherence of slime-producing strains of Staphylococcus epidermidis to smooth surfaces. Infection and immunity. 1982; 37(1): 318-26.

11. Freeman DJ, Falkiner FR, Keane CT. New method for detecting slime production by coagulase negative staphylococci. J Clin Pathol. 1989; 42(8): 872-4. https://doi.org/10.1136/jcp.42.8.872

12. Mortazavi H, Nakhaei Moghaddam M, Abadi NS. Study of the Effect of Silver Nanoparticles on Biofilms Formation by Staphylococcus epidermidis. Journal of Rafsanjan University of Medical Sciences. 2015; 14(2): 125-36.

13. Rahimi F, Bouzari M, Maleki Z, Rahimi F. Antibiotic susceptibility pattern among Staphylococcus spp. with emphasis on detection of mecA gene in methicillin resistant Staphylococcus aureus isolates. Iranian Journal of Clinical Infectious Diseases. 2009; 4(3).

14. Arciola CR, Baldassarri L, Montanaro L. Presence of icaA and icaDGenes and slime production in a collection of Staphylococcal strains from catheterassociated infections. Journal of clinical microbiology. 2001; 39(6): 2151-6. https://doi.org/10.1128/JCM.39.6.2151-2156.2001

15. Panda PS, Chaudhary U, Dube SK. Comparison of four different methods for detection of biofilm formation by uropathogens. Indian J Pathol Microbiol. 2016; 59(2): 177. https://doi.org/10.4103/0377-4929.182013

16. Hassan A, Usman J, Kaleem F, Omair M, Khalid A, Iqbal M. Evaluation of different detection methods of biofilm formation in the clinical isolates. Braz J Infect Dis. 2011; 15(4): 305-11. https://doi.org/10.1016/S1413-8670(11)70197-0

17. Deka N. Comparison of Tissue Culture plate method, Tube Method and Congo Red Agar Method for the detection of biofilm formation by Coagulase Negative Staphylococcus isolated from Non-clinical Isolates. Int J Curr Microbiol App Sci. 2014; 3(10): 810-5.

18. Arslan S, Özkardes F. Slime production and antibiotic susceptibility in staphylococci isolated from clinical samples. Memórias do Instituto Oswaldo Cruz. 2007; 102(1): 29-33.

19. Satorres SE, Alcaráz LE. Prevalence of icaA and icaD genes in Staphylococcus aureus and Staphylococcus epidermidis strains isolated from patients and hospital staff. Cent Eur J Public Health. 2007; 15(2): 87-90.

20. Kord M, Ardebili A, Jamalan M, Jahanbakhsh R, Behnampour N, Ghaemi EA. Evaluation of Biofilm Formation and Presence of Ica Genes in Staphylococcus epidermidis Clinical Isolates. Osong Public Health Res Perspect. 2018; 9(4): 160. https://doi.org/10.24171/j.phrp.2018.9.4.04

21. El-Khier NTA, El-Kazzaz SS, Elganainy AE. Phenotypic and Genotypic Detection of Biofilm
Formation in Staphylococcus epidermidis Isolates from Retrieved Orthopaedic Implants and Prostheses. $\mathrm{Br}$ Microbiol Res J. 2015; 9(4): 1-10. https://doi.org/10.9734/BMRJ/2015/18650

22. Růžička F, Hola V, Votava M, Tejkalova R, Horvát R, Heroldová M, Woznicová V. Biofilm detection and the clinical significance ofStaphylococcus epidermidis isolates. Folia Microbiol. 2004; 49(5): 596.

23. Gad GF, El-Feky MA, El-Rehewy MS, Hassan MA, Abolella H, El-Baky RM. Detection of icaA, icaD genes and biofilm production by Staphylococcus aureus and Staphylococcus epidermidis isolated from urinary tract catheterized patients. J Infect Dev Ctries. 2009; 3(05): 342-51.

24. Oliveira A, Maria de Lourdes RS. Comparison of methods for the detection of biofilm production in coagulase-negative staphylococci. BMC Res Notes. 2010; 3(1): 260. https://doi.org/10.1186/1756-0500-3-260

25. Rohde H, Burdelski C, Bartscht K, Hussain M, Buck F, Horstkotte MA, Knobloch JK, Heilmann C, Herrmann M, Mack D. Induction of Staphylococcus epidermidis biofilm formation via proteolytic processing of the accumulation-associated protein by staphylococcal and host proteases. Molecular microbiology. 2005; 55(6): 1883-95.

26. Tormo MA, Knecht E, Götz F, Lasa I, Penades JR. Bap-dependent biofilm formation by pathogenic species of Staphylococcus: evidence of horizontal gene transfer?. Microbiology. 2005; 151(7): 2465-75. https://doi.org/10.1099/mic.0.27865-0

27. Ziebuhr W, Krimmer V, Rachid S, Lößner I, Götz F, Hacker J. A novel mechanism of phase variation of virulence in Staphylococcus epidermidis: evidence for control of the polysaccharide intercellular adhesin synthesis by alternating insertion and excision of the insertion sequence element IS256. Molecular microbiology. $\quad 1999 ; \quad 32(2)$ : $345-56$. https://doi.org/10.1046/j.1365-2958.1999.01353.x

28. Kozitskaya S, Cho SH, Dietrich K, Marre R, Naber K, Ziebuhr W. The bacterial insertion sequence element IS256 occurs preferentially in nosocomial Staphylococcus epidermidis isolates: association with biofilm formation and resistance to aminoglycosides. Infection and immunity. 2004; 72(2): 1210-5. https://doi.org/10.1128/IAI.72.2.1210-1215.2004 